\title{
Transformational Growth within the Monetary Circuit
}

\author{
Parasal Devinim Sürecinde Dönüșümsel Büyüime
}

\author{
Assist. Prof. Dr. Dicle Özdemir
}

Başvuru Tarihi: 09.04.2018

Kabul Tarihi: 10.12 .2018

\begin{abstract}
Endogenous money view can be described as the supply of money is not under the absolute control of the central banks and emerges endogenously within financial markets, market structure and credit availability. Most importantly, the theory of endogenous money reveals enormous significance of the source of interest rates in the definition of financial fragility. The aim of this article is to present the post-Keynesian theme of the monetary circuit as argued by the General Theory of Transformational Growth. According to this approach, capital adequacy requirements are procyclical, and for this reason, it is important to analyze the relationship between the growth rate and the rate of interest, since the growth of bank capital is tied to the latter.
\end{abstract}

Keywords: Endogenous Money, Growth, Interest Rate, Liquidity, Post-Keynesian

\section{Öz}

Paranın içselliği görüşü, para arzının merkez bankalarının mutlak kontrolü altında olmadiğ ve finansal piyasalar, piyasa yapısı ve kredi kullamılabilirliği içinde içsel olarak ortaya çıktığ s şeklinde tanımlanabilir. Daha da önemlisi, endojen para teorisi, finansal kırllganlık tanımında faiz oranlarının kaynağının büyük önemini ortaya koymaktadır. Bu makalenin amaci, parasal döngünün Post-Keynesyen temasıni, Dönüşümsel Büyüme yaklaşımı ile sunmaktır. Bu yaklaşıma göre, sermaye yeterliliği gereklilikleri döngüseldir ve bu nedenle, banka sermayesinin büyümesi faiz oranına bağlandı̆̆ından, büyüme oranı ve faiz oranı arasındaki ilişkinin yakından incelenmesi gerekmektedir.

Anahtar Kelimeler: Paranın İçselliği, Büyüme, Faiz Orani, Likidite, Post-Keynesyen

\section{Introduction}

The inclination of money supply curve and the compatibility of money endogeneity with the theory of liquidity preference lead to an important debate amongst the Post-Keynesians. Accomodationists such as Nicholas Kaldor (1981) and Basil Moore (1988a, b) argue that the money supply is entirely credit driven, that is, with exogenously determined interest rate, monetary authorities and commercial banks manage reserves in an accommodating manner. According to them, the accommodation of the private sector demand for money is a structural necessity in a modern financial system. In contrast, Structuralists argue that interest rate in an economic system might be endogenously determined; that is, the money supply is influenced by the demand for credit and the monetary authorities, but they also argue that the money supply also depends on the asset and liability management of banks (Palley, 1997, 2001). Moreover, even if the

Assist. Prof. Dr. Dicle Özdemir, Muğla Sttkı Koçman University Faculty of Economics and Administrative Sciences, dicleozdemir@mu.edu.tr, ORCID: 0000-0002-7594-1054 
monetary authorities refuse to supply any additional reserves, banks would still be able to accommodate this increase in demand through their own reserves (Lavoie, 1986).

Indeed, although the Post-Keynesian theory draws attention to the endogenous money approach, the real innovation of them is the construction of endogenous money concept in terms of bank lending. The interaction between banks and customers shifts attention toward the asset side of bank balance sheets. When the demand for loans increase, banks can make more loan and banking deposits, without worrying about the quantity of reserves they have. This may lead to "credit money" concept be thought of as a horizontal leveraging of reserves with no fixed leverage ratio. A problem appears at this point; the conventional theory would miss that there is structural difference between fiat money and credit money (Wray, 2007).

The endogenity of money stock approach leads Kaldor and Moore to reach the conclusion that the rate of interest is exogenous in the sense that it is set by the decision of central bank. However, Minsky draws attention to the efficiency of an increase in interest rates in the short run as a contractionary monetary policy in financial environments fostered by financial innovations. On the other hand, in the long run, the monetary contraction may be rendered ineffective by financial innovations through a higher velocity of money (Minsky, 1957:183; Aktaran: Mollo, 1999:6). This is why when money could not be created due to high liquidity preference, banks would fail to accommodate the liquidity needs of the economy, and may also cause financial instability.

While the horizontal money supply curve requires the interest rates cannot be determined endogenously, and as the economy reaches a peak, interest rates will not necessarily rise. However, the American post-war experience shows that interest rates can be procyclical. At this point, it may be appropriate to introduce Nell's version of financial instability based on technological transformations. The Transformational approach, initiated by Edward Nell (1998), is one of the most important approaches to understanding the Post-Keynesian thought. Its main contribution is to show that economic growth is linked to structural changes in the economy and to innovations under the process of 'Transformational Growth'. In the short run, prices tend to be fixed, on account of constant costs and no marginal productivity conditions with the flexibility of employment, so that adjustment takes place through the multiplier accelerator. If investments are 'extensive', then growth will occur such as new plants, equipment, facilities and projects. Otherwise, in the manner of 'intensive', profits are reinvested into the reorganization and reconstruction of present facilities. But, as Nell states, whichever it is, the plans for growth should be developed in conjunction with plans for prices due to the expected growth of the market that will depend in part on the anticipated prices (Nell, 1998). This discussion reveals enormous importance of the source of interest rates in the definition of financial fragility. This study will show how Nell's "The General Theory of Transformational Growth" validates both Minsky's view on debt burden and financial fragilities and Lavoie's argument against Minsky about debt/equity ratio within the context of financial cycles.

Nell develops cyclical patterns of growth to link the interaction between the financial and real aspects of the economy and financial innovations and institutions. There are primary two different technologies, "Craft-based production" and "Mass Production", based on the idea that $t$ labor markets work differently under different technologies due to the different costs. The structure of these two patterns depends on adjustment of employment and output to variations in sales and costs. However, the production functions of both types should be understood in a Marshallian concept and neither the Craft nor the Mass Production system "allows for a labor market in which there will be an adjustment process that would tend to move the system towards a position in which all labor seeking jobs will find employment at a determinate wage", as Nell emphasized (Nell, 2007:180).

\section{Transformational Growth and Production Systems}

Nell provided an economic basis for the distinction between Mass Production and Craft-based Production systems. The Mass Production economy is unstable on account of monetary and financial systems; on the contrary, the labor and commodity markets are volatile and constrained by the financial system. Financial markets exacerbate the instability because 
the cycle leads to systematic pressures on firms and this process causes insufficient ability to compete. This volatile mechanism amplifies external shocks by the 'multiplier accelerator' (Nell, 1998). Since World War II, real wages have been appeared to be positively correlated with levels of employment. A rise in the growth of demand will tend to lead to a rise in productivity and a rise in the real wage. By means of weakly countercyclical budget and discretionary policy, the government has to provide stabilization. On the contrary, the Craft Production economies, as the early capitalist societies, were characterized by a stabilizing price mechanism. A rise in demand brought a fall in the real wages in the short run, but this tended to become stable. In other words, when investment or exports fell, reflecting uncertainties and shifts in expectations, prices would fall relative to money wages, leading to a rise in real wages and thus consumption spending (Nell, 1998, 2004). Moreover, in Craft Economy, expectations were adaptive, this is because there were not enough information on how markets adjust or the causes of booms and crises. The only key for future was past experiments, which can be called adaptive expectations. By contrast, in Mass Production, expectations can be formed in greater detail and by the statistical indicators, signs of changes can be predicted, so expectations are hold. And with this greater flow of information, "a distribution of beliefs can be expected, of more or less normal shape, centered around the correct turning point", as Nell says (Nell, 1998:657).

In a Craft Economy, the real wage could be negatively related to the employment due to the assumption that economy is normally working subject to decreasing returns. Under this circumstances and assuming a competitive economy, the prices will be equal or proportional to marginal cost, which would imply a corresponding relationship between the real wage and the marginal product of labor. Moreover, according to Nell (1998), in a Craft Economy, the more intensive use of capacity would imply higher unit running costs. Hence, this production system tends to produce at the minimum point of the average cost curve, for that reason the level of production was not so flexible. Besides in Craft Economy workers are highly skilled, with a good knowledge of practical engineering (hierarchical organization). With respect to the firms, they are small or medium-size, run by hands-on management. In other words, changing the level of out- put tends to be difficult and costly. Contrary to Craft Economy, in a Mass Production environment, since the real wage is positively related to employment, prices do not play an important role in adjustment to changing demand under more flexible employment conditions (Nell, 1998).

In sum, during the Craft Production period, covering a broad period from 1870 to 1914 dominated by craft based technologies, markets adjust through a weakly stabilizing price mechanism, but after that period to present, as the economy shifted to mass production, there is no evidence of such a price mechanism; that is, multiplier-based adjustment replaces price mechanism which also reflects a capital-stock adjustment process and the change of technology to mass-production. Since the multiplier implies a procyclical pattern of movement of employment and output, Nell shows that important financial variables are also procyclical and this confirms that the Mass Production economies contain important tendencies to instability. At this point, it is more appropriate to introduce the "Minsky-Nell Approach".

\section{The Minsky-Nell Perspective on Increasing Risk}

In his influential work, The General Theory of Transformational Growth, Nell introduced an economic theory and asserted that when actual growth tends to outrun normal trend rate, the wage-price spiral will tend to squeeze profits. In fact, this comes from a cyclical mechanism. In other words, an upward movement reinforces itself, and then overshoots normal levels. But this will lead to higher costs until further expansion, which results in a downswing, and then reinforcing and overshooting itself again. And a decline in costs takes place until a lower turning point. (Nell, 1998)

While this process requires a number of behavioral functions, it should be noted that these behavioral functions are not based on profit maximization made by rational agents, instead these changes come from the changes on macroeconomic variables (Nell, 1998). Nell defines two functions, the $\mathrm{rE}$ function will show the profits generated by the various possible levels of investment spending and the ISF function is based on the financing of investment spending, and shows the level of profits needed to support a given level of in- 
vestment spending, in the light of the way that spending is financed, and in the light of the risk entailed by that level of investment activity, in other words, it shows the level of current profits required to continue the current level of investment spending. Its intercept depends on autonomous or fixed business costs, and its initial slope depends on the leverage ratio; that is, on how much firms are willing to borrow, given their current profits. Higher levels of leverage bring higher risks and higher borrowing means higher fixed costs; and this, in turn further increases risk. Since risk will rise as the level of current investment spending increases, the ISF curve will turn up. When interest rates fall, a higher degree of leverage can be tolerated, and also the degree of risk will be lower - so the slope of the IF declines, and its curvature flattens. When interest rates rise, acceptable leverage falls, and the degree of risk rises, so the curvature will increase.

Another important point is that the effect of changes in the state of confidence is to increase or decrease of the curvature of the investment function. If the confidence falls, a higher subjective risk premium must be added and the curvature will be increasing to the upward, or when it rises, a subjective factor can be subtracted from risk, and the curvature will be flattened. On the other hand, the cost of falling to meet the obligations will be larger with the planned level of investment spending. So, according to Nell, the sum measuring risk is the product of the probability of failure times the anticipated cost of failure, and the rate of return that would compensate for risk is the sum divided by the capital in the market. In the case of an increase in the probability and the cost of failure at a constant rate with planned investment spending, the sum at risk would rise at an increasing rate. So, risk can be added to the IF (investment finance) curve and leads to it to turn up and rise at an increasing rate with investment spending. The urgent necessity of higher levels of investment will be lower and the required cash flow coverage will be proportionally higher.

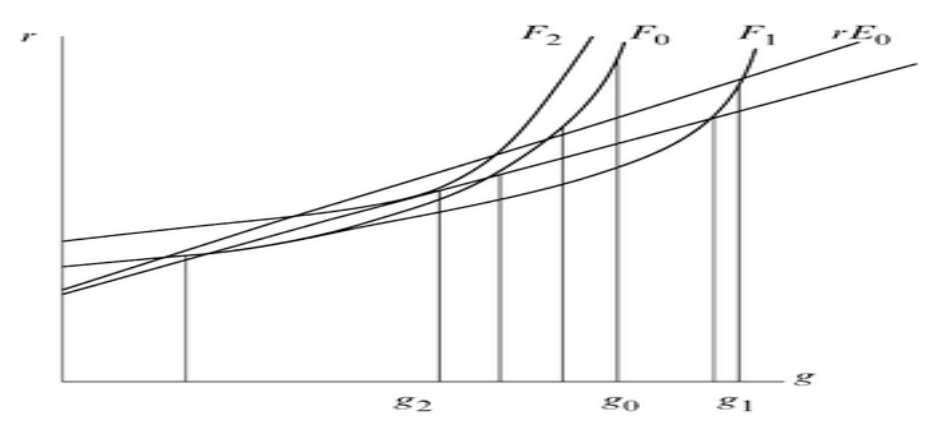

Figure 1. Increasing Risk (Nell, 1998, p.665)

As it can be seen from the Figure-1, there are three possibilities, depending on the position of the $\mathrm{rE}$ (the rate of return generated through the multiplier by different levels of investment expenditure), with respect to the IF. From the first $r E$, we can see that the IF could cut $\mathrm{rE}$ from below, the second $\mathrm{rE}$ shows that it could intersect $\mathrm{rE}$ twice, and the third shows that it could be just tangent. So, when the IF cuts the rE from below, investment spending will be stable. But if it intersects from above, investment will be unstable and the tangent point is unstable downwards. When the IF cuts the rE from below, and if the growth is low, the system will expand in a boom, whereas if growth is high, and the IF is tangent, there will be a downswing (Nell, 1998, p. 662-665). 


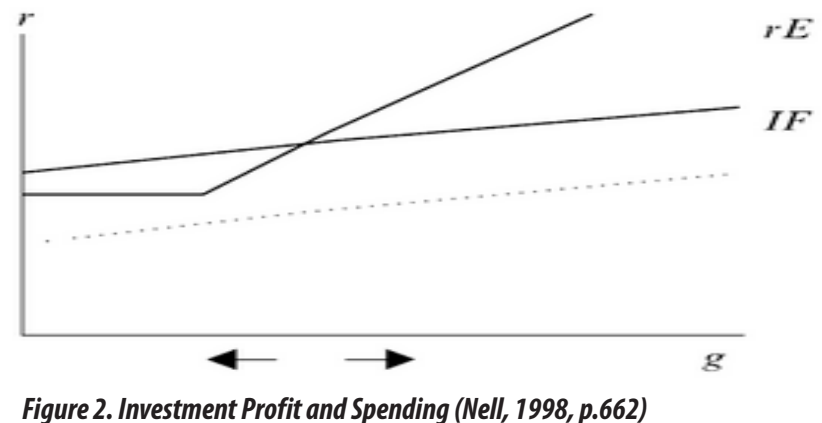

Figure 2. Investment Profit and Spending (Nell, 1998, p.662)

If there is a possibility of an upswing, firms must have an inventory at the ready, and similarly, when downswing looms, firms must be careful about cutting inventory. Shortly, investments are generated by the anticipated level of current spending. And the higher this is, the lower the probability of failure and so the lower the risk; hence, the higher will it be investment spending. In conclusion, the Minsky-Nell approach is developed as demand determined by Nell, and, the model allows for cost and supply variations with financial-real issues and increasing risk. More importantly, investment is at the center of the model and this lead to balancing the gains from investment against the costs and risk. Because interest affects both the intercept and slope of the IF curve, it also affects its intersections with the $\mathrm{rE} \mathrm{line.} \mathrm{An} \mathrm{increase} \mathrm{in} \mathrm{in-}$ terest rate will therefore lead to a decrease in investment spending but after a lag, an adjustment takes place that means the rate of interest will accommodate the rate of growth (Nell, 1998, p.662-665).

\section{Circulation Dynamics and Money Supply}

In Post-Keynesian theory, the amount of money in circulation in the economy is determined endogenously. In this respect, the sum of money in circulation will be equal to the wage bill of the capital good sector, that is, the amount of money that is necessary and sufficient to carry out all the economic transactions. Under these conditions, the rate of interest will be determined by the supply and demand for banking reserves ${ }^{11}$.

1 In this explanation, we assume that in the short run the Quann tity Equations applies, that is greater amount of money will temporarily increase prices. However in the long run money adjust, so the amount of money is endogenously determined (see Nell, 2004).
With regard to the first claim, we know that, in general, enterprises first produced goods and services and then they receive income from sales. That is, companies need access to credit. Therefore, the financial requirements to carry out productive investment are crucial in the demand for bank credit. So, once the credit is granted, commercial banks agreed to pay an amount of money to the balance sheet of the enterprises, causing that the liabilities grow pari passu with the banking assets. Thus, the amount of money for current transactions is created endogenously. However, if companies expect that the demand for consumer goods will be low, then the financial process works in reverse. The companies will use part of their sales to reduce the current annual volume of loans and working capital and in the absence of other lenders who want to expand their loans, the total money supply will decline endogenously. However, the previous position did not mean that banks will be passive in the granting of credits. The banks deny credit to those applicants who do not meet the sufficient conditions (i.e. appropriate collateral).

Transformational Growth Theory asserts that arbitrage plays a crucial role in Mass Production systems. Nell makes the very interesting observation that "changes in the money supply neither cause nor require changes in interest rates in the short run, as contrary to the conventional theory. Changes in the money supply reflect spending; they do not cause it "(Nell, 1998, p. 663). So it is time to look at the cycle in relation to the expansion and austerity. Nell shows the interaction of the real and financial sides of the economy on a diagram with the real interest rate and the growth rate. When we look at expansionary regime first on Figure-2, where $i<$ g, we can see that the $\mathrm{rE}$ lies above the 
IF, which means that investment spending lead to an excessive cash flow. And this creates an upswing, investment spending rises and increasing risk turns the IF up to intersect with the rE. This process will end in a strong productivity growth with higher stock prices. This appreciate will cause an increase at interest rates. But the higher stock prices will not lead to boom, instead a self reinforcing expansion. This expansion will be end at a point where the system has reached the uper equilibrium. At his point, real interest rates will fall during the period of the turning point, but inflation will also slow down and this will allow rates of interest begin to recover (Nell, 1998). The banking system will set higher interest rates to operate costs, thus at some point, interest rate will begin to rise further and intensify the downward pressure. At the bottom, where banks will reorganize and cut back fixed costs, $\mathrm{F}$ will begin to decline. This shifts the IF down again. This will tend to lower interest rates slowly, but at the end $\mathrm{rE}$ will recover and IF will decline until the point where expansion can begin again (Nell, 1998).

The most crucial point of Nell's analysis comes with a disequilibrium perspective, the instability of $i$ and $g$, whether they move together or this is not likely. Nell demonstrates that in craft economies, where output tends to be fixed, g may be limited, but in mass economies, g will vary strongly. Moreover, low interest rates encourage expansions, while higher rates discourage it. So it is natural to expect $\mathrm{i}>\mathrm{g}$ in the slump, while $\mathrm{i}<\mathrm{g}$ in the boom.

It should be clear that there is a tendency to lead the inequalities and Nell emphasizes this potential instability, and points out the analytic potential of this kind of procedure. According to him, interest rates lower than the growth rate tend to encourage investment, thus tend to raise growth rate which eventually leads to inflation. Inflation will then tend to support for the case $i<g$, which encourages spending and expansion with raising $g$, while it will reduce real interest rate. The interest rates that greater than growth will discourage investments, and dampen inflation. This process will cause an opposite effect. When interest rate is higher than the growth rate, declining inflation will support interest rate, and discourage spending.

When Nell studied the inequality between I and g, he also agreed that four significant long-term changes take place under the pro-longed inequality cases (Nell, 1998, p.691-692).
1. The Ratio of Debt: When $\mathrm{i}<\mathrm{g}$, corporate debt will tend to be falling as a ratio to total output, and when $\mathrm{i}>\mathrm{g}$, it will tend to rise.

2. Expansion of Financial Sector: An expansion of the financial sector leads to increases of the operating costs that have to be covered by financial earnings. This will lead to a downward flexibility for i. nevertheless, the volume of business, which will grow at the rate g, leads to an upward pressure on $i$.

3. The Ratio of Idle Funds to Active Funds: When $\mathrm{i}>\mathrm{g}$, this ratio will be high and will tend to rise; when $\mathrm{i}>\mathrm{g}$, it will be low and tend to fall. In other words, when i $>$ g, liquidity has a high opportunity cost. Or when $i<g$, the banking and financial system will be relatively stagnant.

4. Income distribution: When $\mathrm{i}>\mathrm{g}$, there will be pressures to increase inequality, because investments in human capital will fall, and the earnings will not be much as expected.

To sum up, $i$ and $g$ are normally not equal in advanced financial regimes; that is, as Nell pointed out, the real rate of interest fluctuates at levels that have been persistently above the rate of growth (Nell, 2000). According to Nell, if the real rate of interest is higher than the growth rate, credit will be expensive relative to its uses. This will lead to dampen investments, growth and inflation. The result will be lower real interest rates. The financial markets will tend to boom, while the real side of the economy will tend to be relatively stagnant. Otherwise, when $\mathrm{i}<\mathrm{g}$, there will be fairly strong incentive to invest, and debt will be low and growing slowly. And the proportion of debt to equity claims will tend to be falling. In other words, Nell defines the $i>g$ regime as an expansionary regime with a small financial sector, while the $i<g$ regime has a tendency to stagnation with a large growing financial sector and high probability of asset price speculations (Nell, 2000). Moreover, the shift from the first to the second will require a financial crash and a shakeout of banking system, otherwise, the shift from the second to the first will require a prolonged recession in the real economy, with high unemployment and low growth on a low-productivity economy.

Rochon and Vernengo (2004), formerly students of Nell, argue that the notion of Minsky's financial ins- 
tability hypothesis is valid only in a situation where the rate of interest is greater than the rate of growth. Minsky refers to the influence of the increases at the firms' debt/equity ratio as they borrow from banks above their retained earnings, and even so, this increased debt/equity ratio will eventually lead to a fragility. Rochon and Vernengo argue that a state of Ponzi scheme cannot exist in a regime where the growth rate of an economy is higher than its rate of interest because in a situation where $\mathrm{g}>\mathrm{I}$, the economy will create more than the sufficient profits to allow firms to pay back their initial loans to the banks. Although Rochon and Vernengo accept Lavoie's criticism of Minsky due to the creation of profits as a result of investment growth, they also argue that Lavoie's point as "as firms increase their debt in order to finance their investments, they also increase aggregate profits, thereby alleviating their debt/equity ratio" (Rochon and Vernengo, 2004, p.214), is applicable unless the rate of interest exceeds the rate of growth, otherwise, the financial fragility scenario may develop as in Minsky's approach.

\section{Conclusion}

In the Post-Keynesian literature, endogenous money view can be described as the supply of money is not under the absolute control of the central banks and emerges endogenously within financial markets, market structure and credit availability. However, Structuralists focus on the idea that money demand depends on the state of liquidity preference with a nonhorizantal money supply curve; that is money supply and money demand are independent. According to Post Keynesian "structuralist" view of endogenous money, money supply is determined by the banking system; furthermore, money authorities would only partially accommodate the need for reserves. Accommodationists, such as Kaldor, Moore and Lavoie, argued a horizontal curve, describing a situation in which the central bank sanctions all the amount of money created by the banking system and it supplies reserves demanded and interfere in its cost only by determining the interest rate.

But there have been some shortcomings within these two major wings of Post-Keynesian economics, which lead to an alternative Post-Keynesian appro- ach labeled as "Circulationists" share Kaldor's and Moore's horizontalist argument; however, developed a better foundation for a monetary theory of production in the heterodox tradition, according to Rochon, who is one of the major contributors to the theory of the monetary circuit. They are much concerned with creation and destruction of money. At this approach, banks are at the center of credit creation, and indebtedness process depends on the creation of profits. The most important innovation is the flow approach to credit endogeneity rather than on portfolio decisions or uncertainty (Nell,1998; Rochon, 1999). The money endogeneity is at the core of their model and this rests on the accommodative role of the central banks, but with a constrained setting level of the real rate of interest.

\section{References}

Kaldor, N. (1981). Origins of the New Monetarism. University of Cardiff Press, Cardiff.

Lavoie, M. (1986). Systematic Financial Fragility. Journal of Post Keynesian Economics, Vol. 9, No. 2.

Lavoie, M. (1992). Foundations of Post-Keynesian Economic Analysis. Edward Elgar, England.

Marx, K., Capital, Volume III

Minsky, H. (1957). Central Bank and Money Market Changes. Quarterly Journal of Economics, vol. LXXI, May, no:2.

Minsky, H. (1975). John Maynard Keynes. New York: Columbia University Press

Minsky, H. (1977). A Theory of Systematic Fragility. In Altman and Sametz (eds) Financial Crises, John Wiley and Sons.

Minsky, H. (1982). The Financial Instability Hypothesis: an interpretation of Keynes and an Alternative to Standard Theory. In Inflation, Recession and Economic Policy, Wheatsheaf Books Ltd., Great Britain. 
Minsky, H. (1982). The financial-instability hypothesis: Capitalist process and the behavior of the economy. In Kindleberger, C. P. and J.-P. Lafargue (eds.) Financial Crises, 13-39. New York: Cambridge University Press.

Minsky, H. (1996). The Essencial Caracteristics of Post Keynesian Economics. In G. Deleplace and E. Nell (ed.), Money in Motion, Macmillan Press, London.

Mollo, M. L. R. (1999). The endogeneity of money: PostKeynesian and Marxian concepts compared. http:// www.countdownnet.info/archivio/teoria/168.pdf

Moore, B. (1988a). The Endogenous Money Supply. Journal of Post Keynesian Economics, vol.X, n.3.

Moore, B. J. (1988b). Horizontalists and Verticalists: The Macroeconomics of Credit Money. Cambridge, Cambridge University Press.

Moore, B. (1991). Money Supply Endogeneity: 'reserve price setting' or 'reserve quantity setting? In Journal of Post Keynesian Economics, vol.13, n. 3

Nell E.J. (1990). The quantity theory and the mark-up equation. Economie Appliquée, XLIII(2), pp. 33-42.

Nell, E. J. (1998). The General Theory of Transformational Growth. Cambridge: Cambridge University Press.

Nell, E. J. (2000). Transformational Growth and Financial Instability: The rate of Interest and The Rate of Growth. VII Jornadas De Economia Critica, Albecete 3-5, Febrero

Nell E.J. (2004). Monetising the Classical Equations: a theory of circulation. Cambridge Journal of Economics, 28, pp. 173-203.
Nell, E. J.(2007). Aggregate Demand, Employment and Eqilibrium with Marginal Productivity. In Pressman, S., Forstater, M. (Ed.), Mongiovi, G. (Ed.). (2007). Post-Keynesian Macroeconomics. London: Routledge.

Nell, E. J. (2008). Transformational Growth: From a Marshallian (almost Neo-Classical) System to Keynesian Growth. (draft version/unpublished).

Palley, T. (1997). Endogenous Money and the Business Cycle. Journal of Economics, 65(2), 133-149. Retrieved from http://www.jstor.org/stable/41794569

Palley, T. (2001). Endogenous Money: What it is and Why it Matters. http://www.thomaspalley.com/ docs/articles/macro_theory/endogenous_money. pdf

Rochon, L. P. (1999). Credit, money, and production: an alternative post-Keynesian approach. Edward Elgar publishing.

Rochon, L. P., Vernengo, M. (2004). Interest Rates, Effective Demand, and Financial Fragility: Edward Nell and The Trieste Tradition. In Growth, Distribution and Effective Demand: Alternatives to Economic Orthodoxy (Essays in honor of Edward J. Nell, edited by G. Argyrous, M. Forstater, and G. Mongiovi, M. E, Sharpe Inc.

Wray, R. (2007). Endogenous Money: Structuralist and Horizontalist. Working Paper No. 512, The Levy Economics Institute and University of MissouriKansas City. 